\title{
Leptin, leptin receptors and hypoxia-induced factor-1 $\alpha$ expression in the placental bed of patients with and without preeclampsia during pregnancy
}

\author{
MIN-JUNG PARK ${ }^{1 *}$, DONG-HYUNG LEE ${ }^{2 *}$, BO-SUN JOO ${ }^{1}$, YOUNG-JOO LEE ${ }^{2}$, JONG-KIL JOO ${ }^{2}$, \\ BEUM-SOO AN ${ }^{3}$, SEUNG-CHUL KIM ${ }^{2}$ and KYU-SUP LEE ${ }^{2}$
}

\begin{abstract}
${ }^{1}$ The Korea Institute for Public Sperm Bank; ${ }^{2}$ Department of Obstetrics and Gynecology, Pusan National University School of Medicine, Biomedical Research Institute, Busan 49241; ${ }^{3}$ Department of Biomaterials Science, College of Natural Resources and Life Science, Pusan National University, Miryang, Gyeongsangnam-do 50463, Republic of Korea
\end{abstract}

Received July 19, 2017; Accepted December 14, 2017

DOI: $10.3892 / \mathrm{mmr} .2018 .8539$

\begin{abstract}
The mechanism underlying the pathogenesis of preeclampsia (PE) has been previously investigated but remains to be elucidated. Among numerous biomarkers that are associated with the pathogenesis of PE, leptin is most frequently investigated. Although studies concerning the association between PE and the expression of leptin in the serum and placenta have been conducted, the results are conflicting and inconsistent. Furthermore, the expression of leptin and its receptors in the placental bed and their association with $\mathrm{PE}$, to the best of our knowledge, has not been previously reported. Therefore, to determine the association between the expression of leptin and its receptor, and pathogenesis and onset period of PE, placental bed tissues were obtained from cesarean section deliveries. The mRNA and protein expression levels of leptin and its receptor were investigated in normal pregnancies $(n=18)$, pregnancies complicated with early-onset PE $(n=9)$ and late-onset $\mathrm{PE}(\mathrm{n}=9)$ by reverse transcription-quantitative polymerase chain reaction and western blotting, respectively. The results demonstrated that the mRNA and protein expression of leptin in the placental bed was significantly increased in the PE groups compared with normal controls and was associated with the onset period of PE. Furthermore, as evidenced by immunostaining, leptin was upregulated in endothelial cells of the placental bed in the PE groups, with a particularly strong upregulation in activated endothelial cells from patients with
\end{abstract}

Correspondence to: Professor Seung-Chul Kim, Department of Obstetrics and Gynecology, Pusan National University School of Medicine, Biomedical Research Institute, 179 Gudeok-Ro, Seo, Busan 49241, Republic of Korea

E-mail: ksch0127@naver.com

\section{${ }^{*}$ Contributed equally}

Key words: preeclampsia, placental bed, hypoxia-induced factor-1 $\alpha$, leptin, leptin receptor early-onset PE. The results of the present study indicate that altered expression of leptin in the placental bed may contribute to the pathogenesis of $\mathrm{PE}$.

\section{Introduction}

Preeclampsia (PE) is a pregnancy-specific syndrome that is characterized by hypertension and proteinuria following 20 weeks of gestation (1). Although it is a major contributor to maternal and perinatal morbidities, mechanisms underlying the pathogenesis of PE have not been elucidated. Various potential etiologies associated with development of PE have been investigated, including angiogenesis imbalance, coagulation abnormalities, immunological maladaptation and exaggerated inflammatory response (2-4). Among the etiologies of PE, incomplete spiral artery remodeling, leading to dysregulated uteroplacental perfusion and placental oxidative stress, is considered to markedly impact the development of PE $(2,3)$. Remodeling of spiral arteries during human pregnancy is precisely regulated by angiogenic factors and their associated receptors (5-7). One potential mechanism underlying PE may be associated with faulty vascular transformation of the uteroplacental unit due to an imbalance in levels of angiogenic factors and hypoxia-induced oxidative stress $(5,7)$.

Leptin, a 16-kDa protein encoded by the $o b$ gene, is secreted by adipose tissues and functions in the regulation food intake and energy expenditure (8). During pregnancy, leptin is also produced in syncytiotrophoblasts and endothelial cells of the placenta $(9,10)$. Furthermore, in a previous study, leptin secretion in BeWo cells (villous trophoblast tumor-derived cells) increased under hypoxic conditions, and these observations indicate that placental production of leptin may be upregulated in severe PE (11).

The pathophysiological role of leptin in the placental bed of patients with PE is currently unclear. However, it has been hypothesized that leptin may serve a role in the pathogenesis of PE by regulating angiogenesis and vascular smooth muscle cell development in the placenta and placental bed (12-15). Among previous reports concerning the angiogenic properties of leptin, Sierra-Honigmann et al (12) indicated that it may 
demonstrate angiogenic activity, and leptin has also been hypothesized to promote angiogenesis through activation of vascular endothelial growth factor (VEGF) receptor 2 (13). However, Islami et al (14) reported that leptin reduces the release of VEGF in cytotrophoblasts in a dose dependent manner, while Bohlen et al (15) demonstrated that leptin inhibits growth and decreases the number of human vascular smooth muscle cells by downregulating the short isoform of leptin receptor.

Another potential mechanism of leptin activity is regulation of inflammatory mediators in the placenta $(16,17)$. Normal pregnancy promotes a mild systemic inflammation, as evidenced by the activation of leukocytes in the blood (18). $\mathrm{PE}$ exacerbates this maternal response in the presence of an embryo and placenta (18). Furthermore, the development of $\mathrm{PE}$ is associated with activation of the coagulation-hemostasis system (19). Activated platelets stimulate leukocyte activity by secreting cytokines (20).

Leptin may serve a role in the placenta by stimulating maternal energy resources for fetal use and development, via leptin receptors, which are present in several isoforms. The long isoform of the leptin receptor activates the mitogen-activated protein kinase cascade in human placental tissue, while the mechanism and action of the short isoform is less understood $(21,22)$. Regulation of leptin and its receptors in the uteroplacental unit remains to be elucidated. One study reported that the expression of leptin receptors is induced under hypoxic conditions in vitro (23); however, the use of human placenta from patients with PE demonstrates conflicting results (22). To date, to the best of our knowledge, there have no previous reports concerning the expression of leptin receptor isoforms in the placental bed tissue, therefore, the present study aimed to elucidate the expression pattern of leptin receptor mRNA and protein in patients with PE.

In previous studies, hypoxia inducible factor-1 (HIF-1), a major regulator of the hypoxic response, was indicated to function as a mediator of leptin expression $(24,25)$. HIF-1 is composed of a heterodimeric HIF- $1 \alpha / \mathrm{HIF}-1 \beta$ complex and hypoxia leads to enhanced leptin expression via HIF-1 $\alpha$ (24). Previous reports have also demonstrated an association between hypoxia and leptin in PE $(26,27)$.

The present study aimed to determine alterations in the expression of these factors in placental bed tissue. Despite the perception that pathophysiological alterations of placental bed tissue are implicated in pathogenesis of $\mathrm{PE}$, research into further understanding the placental bed has not been conducted due to difficulty in obtaining a sample containing spiral artery areas. The term 'placental bed' was introduced by Dixon and Robertson in 1958 and described as the remaining part of the junctional zone that adheres to the uterine wall following delivery (28). The placental bed may be broadly described as part of the decidua and adjoining myometrium containing uterine spiral arteries, whose primary function is the maintenance of a sufficient blood supply to the intervillous space of the placenta $(28,29)$. It was previously reported that the density of extravillous trophoblasts and depth of invasion of uteroplacental arteries are increased in the central region of the placental bed (30).

Previous studies on expression of leptin, leptin receptor and HIF-1 $\alpha$ during pregnancy are limited in the placental tissue and serum and to the best of the authors knowledge, no studies have been conducted using placental bed (10,11,31-35). Currently, to the best of our knowledge, no previous studies have investigated the expression of these factors in the placental bed of women with PE. Therefore, the purpose of the present study was to investigate the association between the expression of leptin, isoforms of leptin receptor and HIF-1 $\alpha$ in the placental bed of pregnant females with and without PE.

\section{Materials and methods}

Study participants. A total of 36 pregnant women (32 \pm 4.8 years), 18 with normal pregnancies, 9 with early-onset PE (EOPE) and 9 with late-onset PE (LOPE) were included in the present study. The Institutional Review Board of Pusan National University Hospital approved the research protocol of the present study (approval no. 1302-005-015) and all participants signed written informed consent forms prior to recruitment. PE was diagnosed based on increased blood pressure $(\geq 140 / 90 \mathrm{mmHg}$ ) that occurred in pregnant women following 20 weeks of amenorrhea accompanied by proteinuria ( $\geq 0.3 \mathrm{~g} / 24 \mathrm{~h}$ or $1+$ dipstick value of protein concentration in urine), using criteria defined by the report of the American College of Obstetricians and Gynecologists Task Force on Hypertension in Pregnancy (1). EOPE and LOPE were defined as those diagnosed at $<34$ and $\geq 34$ weeks gestation, respectively (36).

Placental bed collection. Placental bed tissues were collected from 18 patients with PE (9 with EOPE and 9 with LOPE) and 18 gestational age-matched normotensive controls of third trimester pregnancies at Pusan National University Hospital (Busan, Korea) between May 2014 and December 2015. To avoid the effect of labor on the results, only individuals that delivered by cesarean section were included. Placental bed tissues were sampled using punch biopsy forceps by a single operator as previously described by Dixon and Robertson (28). Tissue samples were washed with $0.9 \% \mathrm{NaCl}$ and placed in sterile tubes. These were stored at $-70^{\circ} \mathrm{C}$ until subsequent extraction of total RNA and proteins or fixed in $4 \%$ paraformaldehyde for $16-24 \mathrm{~h}$ at room temperature prior to histological analysis. All placental bed tissue was verified by immunostaining with antibodies against cytokeratin (1:50; cat. no. ab7753; Abcam, Cambridge, MA, USA) to detect trophoblast and against desmin (1:100; cat. no. ab8592; Abcam) to detect muscle, as previously described (37). Subsequently, confirmed placental bed tissues were used for evaluation of the expression of leptin, isoforms of leptin receptor and HIF-1 $\alpha$.

RNA preparation, reverse transcription-polymerase chain reaction ( $R T-P C R)$ and quantitative PCR ( $P P C R)$. Total RNA was extracted using TRIzol reagent (Thermo Fisher Scientific, Inc., Waltham, MA, USA), according to the manufacturer's protocol. cDNA was synthesized from $1 \mu \mathrm{g}$ total RNA using Avian Myeloblastosis Virus Reverse Transcriptase (Promega Corporation, Madison, WI, USA) using random hexamers (Takara Bio, Inc., Otsu, Japan), $0.2 \mathrm{mM}$ deoxynucleotide triphosphate (dNTP) mixture (Cosmo Genetech, Co., Ltd., Seoul, Korea) and $1 \mathrm{X}$ buffer [50 mM Tris-HCl ( $\mathrm{pH} \mathrm{8.3),}$ $75 \mathrm{mM} \mathrm{KCl}, 3 \mathrm{mM} \mathrm{MgCl}{ }_{2}$ and $\left.10 \mathrm{mM} \mathrm{DTT}\right]$ at $42^{\circ} \mathrm{C}$ for $1 \mathrm{~h}$ 
Table I. Primers sequences used for quantitative polymerase chain reaction amplification and conditions.

\begin{tabular}{|c|c|c|c|c|c|}
\hline \multirow[b]{2}{*}{ Gene } & \multicolumn{2}{|c|}{ Sequence $\left(5^{\prime} \rightarrow 3^{\prime}\right)$} & \multirow{2}{*}{$\begin{array}{l}\text { Annealing } \\
\mathrm{Tm},{ }^{\circ} \mathrm{C}\end{array}$} & \multirow[b]{2}{*}{ Cycles } & \multirow{2}{*}{$\begin{array}{l}\text { Produc } \\
\text { size, bp }\end{array}$} \\
\hline & Forward & Reverse & & & \\
\hline Leptin & GATGACACCAAAACCCTCAT & GGCCACCACCTCTGTGGAGT & 59 & 45 & 354 \\
\hline HIF- $1 \alpha$ & CAGCTATTTGCGTGTGAGGAAA & ACCAAGCAGGTCATAGGTGGTT & 57 & 35 & 471 \\
\hline Leptin-RL & CTAGAGAAGCACTTGGTGACT & GAAGATGTTCCGAACCCCAAGA & 60 & 42 & 428 \\
\hline Leptin-RS & GGGAAGTTGGCACATTGGGTTC & CCATTGAGAAGTACCAGTTCAGT & 60 & 42 & 330 \\
\hline GAPDH & GTGGTCTCCTCTGACTTCAAC & ТСTCTTCCTCTTGTGCTCTTG & 57 & 35 & 212 \\
\hline
\end{tabular}

Tm, temperature; HIF-1 $\alpha$, hypoxia-induced factor $1 \alpha$; leptin-RL, long leptin receptor isoform; leptin-RS, short leptin receptor isoform.

followed by inactivation of the enzyme at $95^{\circ} \mathrm{C}$ for $5 \mathrm{~min}$. Gene expression was assessed using RT-PCR. Each cDNA was subjected to PCR using $2.5 \mathrm{U}$ of Taq polymerase (Cosmo Genetech, Co., Ltd.), 10X Taq buffer, $0.2 \mathrm{mM}$ of dNTP mixture and 100 pmol of each gene-specific primer (Table I). The following thermocycling conditions were used for the PCR: Initial denaturation at $95^{\circ} \mathrm{C}$ for $5 \mathrm{~min}, 35-45$ cycles of denaturation at $95^{\circ} \mathrm{C}$ for $30 \mathrm{sec}$, primer-specific annealing temperature for $30 \mathrm{sec}$ and extension at $72^{\circ} \mathrm{C}$ for $30 \mathrm{sec}$; and final extension at $72^{\circ} \mathrm{C}$ for $10 \mathrm{~min}$. RT-PCR products were visualized on $2 \%$ agarose gels by ethidium bromide staining and UV illumination. Data are representative of at least three independent experiments. The relative density of PCR bands was quantified and normalized to the control GAPDH bands using ImageJ software (version 1.35d; National Institutes of Health, Bethesda, MD, USA). The analytical performance of qPCR and the optimal number of cycles were determined prior to performing RT-PCR. qPCR was performed using SYBR-Green Premix Reagent (Takara Bio, Inc.), as previously described (38). Each experiment was conducted in duplicate and repeated 3 times. The relative expression levels of mRNA in each sample were calculated using the $2^{-\Delta \Delta \mathrm{Cq}}$ method between normotensive control and patients with PE (39). Expression of each gene was standardized to the expression levels of the housekeeping gene GAPDH.

Western blot analysis. Proteins were extracted by mechanical homogenization of placental bed tissues in the presence of $200 \mu \mathrm{l}$ ice-cold lysis buffer [50 mM Tris- $\mathrm{HCl}$ (pH 7.5), $150 \mathrm{mM}$ $\mathrm{NaCl}, 1 \%$ Nonidet P-40, $1 \mathrm{mM}$ EDTA] containing protease inhibitor and extracted protein concentrations were determined using a Bradford assay. A total of $60 \mu \mathrm{g}$ protein/lane was separated by $8 \%$ SDS-PAGE and transferred to a polyvinylidene difluoride membrane. The transfer was performed at a constant voltage of $15 \mathrm{~V}$ for $90 \mathrm{~min}$. For western blotting, the membrane was incubated with anti-leptin polyclonal (1:100; cat. no. sc-842; Santa Cruz Biotechnology, Inc., Dallas, TX, USA), anti-HIF-1 $\alpha$ monoclonal (1:1,000; cat. no. 610958; BD Biosciences, Franklin Lakes, NJ, USA) and anti- $\beta$-actin monoclonal (1:5,000; cat. no. A5316; Sigma-Aldrich, Merck KGaA, Darmstadt, Germany) antibodies in TBS containing $1 \%$ Tween-20 (TBST) supplemented with skimmed milk overnight at $4^{\circ} \mathrm{C}$. Following washing with TBST, blotted membranes were incubated with goat anti-mouse $\operatorname{IgG}(1: 3,000$; cat. no. sc-2005;
Santa Cruz Biotechnology, Inc.) and anti-rabbit IgG (1:5,000; cat. no. sc-2004; Santa Cruz Biotechnology, Inc.) horseradish peroxidase conjugated secondary antibodies for $30 \mathrm{~min}$ at room temperature. Following washing with TBST, protein bands were visualized using an enhanced chemiluminescence detection system (Amersham ECL Advance Western Blotting Detection kit) according to the manufacturer's protocol (GE Healthcare, Chicago, IL, USA). Protein bands were quantified and normalized to the control bands with ImageJ software.

Immunohistochemistry. Serial sections ( $4 \mu \mathrm{m}$ thick) of formalin-fixed, paraffin-embedded placental beds were spread on coated-slides using a microtome and transfer to a $37^{\circ} \mathrm{C}$ water bath with distilled water for $1 \mathrm{~h}$. Slides were deparaffinized in xylene to solubilize and rehydrated in a graded ethanol series (100\% ethanol twice, $95 \%$ ethanol and $85 \%$ ethanol, $1 \mathrm{~min}$ each) at room temperature. The deparaffinized sections were washed with PBS, and microwaved in $10 \mathrm{mM}$ citrate buffer, $\mathrm{pH} 6.0$, for $15 \mathrm{~min}$ in a conventional microwave $\left(98^{\circ} \mathrm{C}\right)$. Subsequently, endogenous peroxidase was quenched by immersion in $0.3 \% \mathrm{H}_{2} \mathrm{O}_{2}$ in methanol for $5 \mathrm{~min}$ as previously described (38). The sections were blocked with $10 \%$ normal rabbit serum (cat. no. ab166640; Abcam) for $30 \mathrm{~min}$ at room temperature to prevent non-specific binding and subsequently incubated with a primary antibody against leptin (cat. no. sc-842; Santa Cruz Biotechnology, Inc.) at a dilution of 1:300 in PBS and 3\% bovine serum albumin (Sigma-Aldich; Merck KGaA) overnight at $4^{\circ} \mathrm{C}$. Following four washes with PBS for $15 \mathrm{~min}$ each, samples were incubated with a biotinylated secondary antibody (diluted 1:200 in PBS; SuperPicture ${ }^{\mathrm{TM}}$ kit; cat. no. 879263; Invitrogen; Thermo Fisher Scientific, Inc.) for $30 \mathrm{~min}$ at room temperature and washed three times with PBS. The samples were subsequently incubated with streptavidin-peroxidase conjugate (Zymed; Thermo Fisher Scientific, Inc.; 1:500 in PBS; cat. no. S-911; Invitrogen; Thermo Fisher Scientific, Inc.) for $30 \mathrm{~min}$ at room temperature followed by an incubation with 3, 3'diaminobenzidine chromogen (Sigma-Aldrich; Merck KGaA). Sections were then rinsed in distilled water, and counterstained for $5 \mathrm{~min}$ in Mayer's hematoxylin (Sigma-Aldrich; Merck $\mathrm{KGaA}$ ) at room temperature and mounted using HistoMount solution (Invitrogen; Thermo Fisher Scientific, Inc.). Results were assessed by two blinded pathologists under a light microscope. 
Table II. Characteristics of study participants.

\begin{tabular}{|c|c|c|c|}
\hline Characteristic & $\begin{array}{l}\text { Normotensive } \\
\qquad(n=18)\end{array}$ & $\begin{array}{l}\text { LOPE } \\
(n=9)\end{array}$ & $\begin{array}{l}\text { EOPE } \\
(n=9)\end{array}$ \\
\hline Age, years & $30.9 \pm 2.3$ & $33.5 \pm 3.6$ & $32.9 \pm 0.37$ \\
\hline Gestational age, weeks & $35.8 \pm 2.4$ & $35.0 \pm 2.0$ & $32.9 \pm 2.1^{\mathrm{c}}$ \\
\hline Parity & $0.9 \pm 0.8$ & $1.0 \pm 1.3$ & $0.6 \pm 0.7$ \\
\hline Gravidity & $2.1 \pm 1.1$ & $2.5 \pm 1.8$ & $2.2 \pm 1.1$ \\
\hline $\mathrm{BMI}, \mathrm{kg} / \mathrm{m}^{2}$ & $26.4 \pm 5.3$ & $25.9 \pm 3.1$ & $26.2 \pm 3.6$ \\
\hline Systolic BP, mmHg & $109.3 \pm 8.0$ & $143.7 \pm 13.7^{\mathrm{a}}$ & $158.0 \pm 13.2^{\mathrm{b}}$ \\
\hline Diastolic BP, mmHg & $68.7 \pm 7.4$ & $86.7 \pm 5.2^{\mathrm{b}}$ & $111.3 \pm 5.0^{\mathrm{b}}$ \\
\hline Neonatal birth weight, $g$ & $2,800.7 \pm 570.4$ & $2,208.3 \pm 504.0^{\mathrm{a}}$ & $1,455.6 \pm 357.3^{\mathrm{b}, \mathrm{d}}$ \\
\hline
\end{tabular}

${ }^{\mathrm{a}} \mathrm{P}<0.05$ and ${ }^{\mathrm{b}} \mathrm{P}<0.01$ vs. the normotensive control; ${ }^{\mathrm{c}} \mathrm{P}<0.05$ and ${ }^{\mathrm{d}} \mathrm{P}<0.01$ vs. the LOPE group. Data are presented as the mean \pm standard deviation. LOPE, late-onset preeclampsia; EOPE, early-onset preeclampsia; BMI, body mass index; BP, blood pressure.

Statistical analysis. All experiments were repeated $\geq 3$ times independently. Statistical analysis was performed with Kruskal-Wallis test followed by Mann-Whitney test and the Bonferroni correction for comparisons between pairs of groups. Results are presented as the mean \pm standard deviation. $\mathrm{P}<0.05$ was considered to indicate a statistically significant difference. The statistical software SPSS 22.0 (IBM Corp., Armonk, NY, USA) was used for data analysis.

\section{Results}

Clinical characteristics of participants. The clinical characteristics of participants of the present study are summarized in Table II. There were no statistically significant differences in maternal age, parity, gravidity and body mass index among the normotensive, LOPE and EOPE groups. Systolic and diastolic blood pressures were significantly increased in the PE groups compared with the normotensive group $(\mathrm{P}<0.01)$. Gestational age at the time of delivery in the EOPE group was significantly shorter compared with the LOPE and normotensive groups $(\mathrm{P}<0.05)$. Birth weights of newborns were significantly lower in LOPE and EOPE groups compared with the normotensive group; furthermore, the EOPE group demonstrated significantly lower birth weights compared with the LOPE group $(\mathrm{P}<0.01)$.

$m R N A$ and protein expression of leptin and HIF-1 $\alpha$ in the placental bed of normotensive, EOPE and LOPE groups. The results of RT-PCR demonstrated that the expression of placental bed leptin mRNA was significantly increased in PE groups compared with the normotensive group. In addition, the leptin mRNA expression level in the EOPE group was significantly increased compared with the LOPE group as analyzed by RT-PCR (Fig. 1A and B). Expression levels of HIF-1 $\alpha$ mRNA in the EOPE group demonstrated a pattern similar to the results for leptin expression (Fig. 1A and B). Furthermore, qPCR analysis demonstrated that mRNA expression levels of leptin and HIF-1 $\alpha$ were increased $\sim 2$-fold (248 and 196\%, respectively) in the EOPE group compared with the normotensive control group (100\%; both $\mathrm{P}<0.01$; Fig. $1 \mathrm{C}$ and $\mathrm{D})$. However, based on RT-PCR results, the expression of leptin
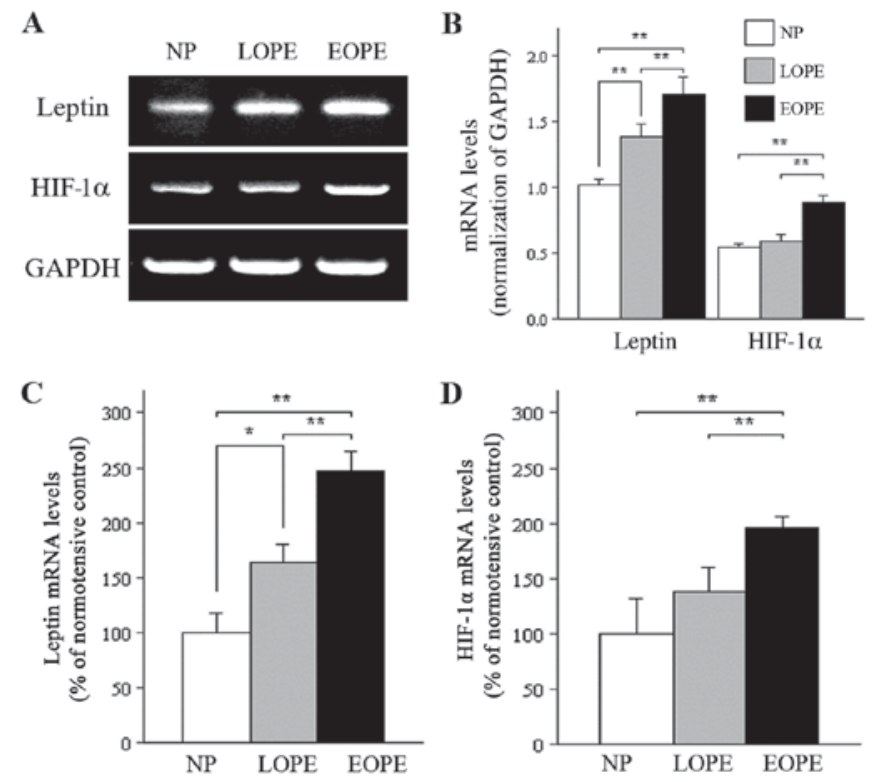

Figure 1. Expression of leptin and HIF-1 $\alpha$ mRNA in the placental bed (A) mRNA expression levels for leptin and HIF-1 $\alpha$ were investigated by RT-PCR (B) Densitometric analysis of leptin and HIF-1 $\alpha$ mRNA expression following RT-PCR. qPCR analysis of (C) leptin and (D) HIF-1 $\alpha$ mRNA levels in the placental bed of normotensive controls and patients with PE. Levels of mRNA for leptin and HIF-1 $\alpha$ were normalized to the amount of GAPDH per sample. Data are presented as the mean \pm standard deviation. ${ }^{*} \mathrm{P}<0.05$ and ${ }^{* *} \mathrm{P}<0.01$, as indicated. HIF- $1 \alpha$, hypoxia-induced factor- $1 \alpha$; RT-PCR, reverse transcription-polymerase chain reaction; qPCR, quantitative PCR; PE, preeclampsia; LOPE, late-onset PE; EOPE, early-onset PE; NP, normotensive pregnant.

receptor isoforms was not significantly different between the $\mathrm{PE}$ and the normotensive groups (Fig. 2). Therefore, qPCR was not performed.

Similar to the results for mRNA expression, western blot analysis revealed that the protein expression of leptin and HIF-1 $\alpha$ in the placental bed was significantly increased in the $\mathrm{PE}$ groups compared with the normotensive group $(\mathrm{P}<0.01$; Fig. 3). In addition, leptin and HIF-1 $\alpha$ protein expression were significantly increased in the EOPE group compared with the LOPE group $(\mathrm{P}<0.01$; Fig. 3$)$. 
A

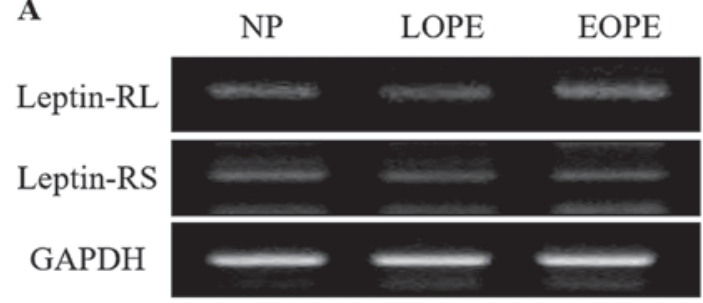

B

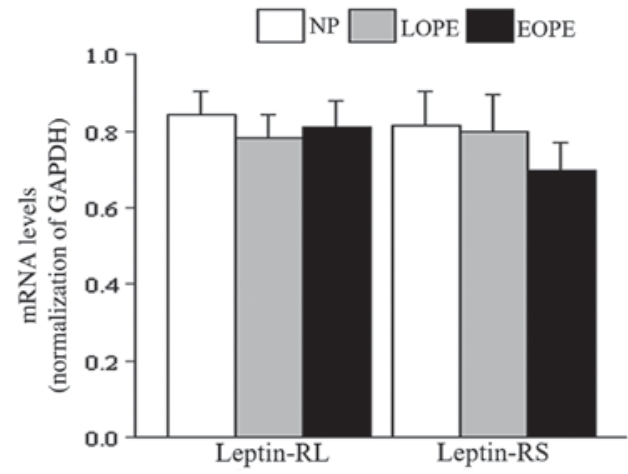

Figure 2. mRNA expression levels of leptin receptor isoforms in the placental bed. (A) RT-PCR products of mRNA expression for leptin-RL and leptin-RS (B) Densitometric analysis of mRNA expression levels of leptin receptor isoforms following RT-PCR. Levels of mRNA for isoforms of leptin receptor were normalized to the amount of GAPDH per sample. Data are presented as the mean \pm standard deviation. RT-PCR, reverse transcription-polymerase chain reaction; leptin-RL, long leptin receptor isoform; leptin-RS, short leptin receptor isoform; LOPE, late-onset preeclampsia; EOPE, early-onset preeclampsia; NP, normotensive pregnant.

Immunohistochemical analysis of leptin expression in the placental bed of normotensive, EOPE and LOPE groups. Immunohistochemistry was performed to investigate the localization of leptin protein in the placental bed. Leptin was positively stained in the endothelial cells of all groups. The endothelial cells of the intima in the EOPE group exhibited increased activation compared with the normotensive group, based on a cuboidal morphology compared with the flattened morphology of the normotensive group, indicating damage of endothelial cells in the EOPE groups (Fig. 4). Endothelial expression of leptin in the EOPE group was increased compared with the LOPE and normotensive control groups, as indicated by more intense staining. These observations indicate that increased leptin expression may be associated with endothelial cell activation in the placental bed.

\section{Discussion}

A number of studies have investigated leptin levels in maternal serum, cord blood and placental tissue in patients with or without PE (10,11,31-35). The majority of studies have reported increased serum leptin levels and increased placental leptin expression in pregnancies with PE compared with normotensive pregnancies $(10,11,34)$. However, conflicting results have also been reported $(31,32,40)$. The present study demonstrated that the expression of placental bed leptin and HIF-1 $\alpha$ were significantly elevated in pregnancies with PE compared with the normotensive control group. To the best of our knowledge, the present study is the first to report on the expression of leptin, leptin receptor isoforms and HIF-1 $\alpha$
A

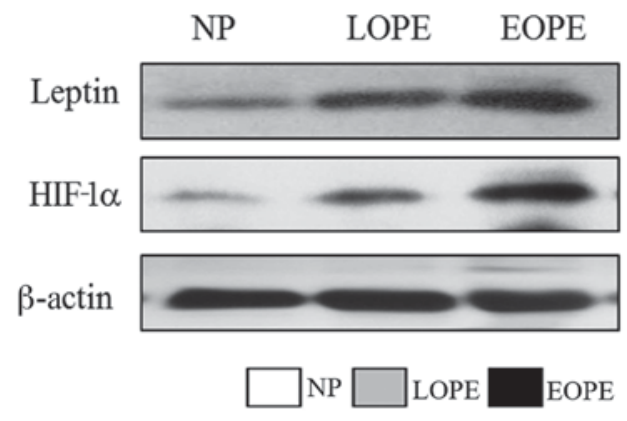

B

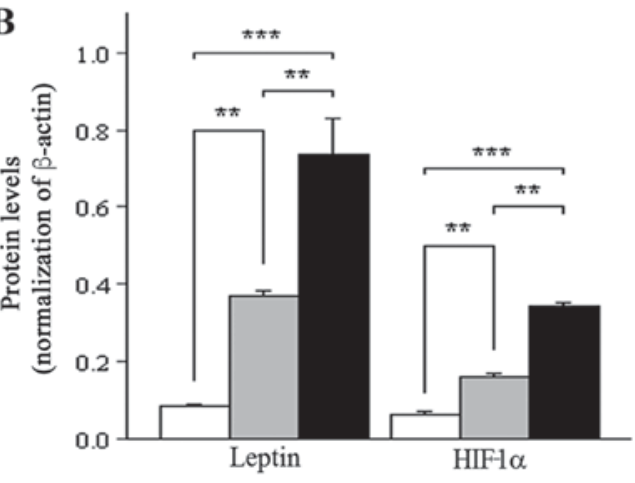

Figure 3. Protein expression levels of leptin and HIF-1 $\alpha$ in the placental bed. (A) Representative western blot bands for leptin and HIF-1 $\alpha$ protein expression in NP, LOPE and EOPE groups. (B) Densitometric analysis of leptin and HIF-1 $\alpha$ protein expression was performed following western blot analysis. Levels of protein for leptin and HIF-1 $\alpha$ were normalized to the amount of $\beta$-actin per sample. Data are presented as the mean \pm standard deviation. ${ }^{* *} \mathrm{P}<0.01$ and ${ }^{* * *} \mathrm{P}<0.001$, as indicated. HIF-1 $\alpha$, hypoxia-induced factor- $1 \alpha$; NP normotensive pregnant; LOPE, late-onset preeclampsia; EOPE, early-onset preeclampsia.

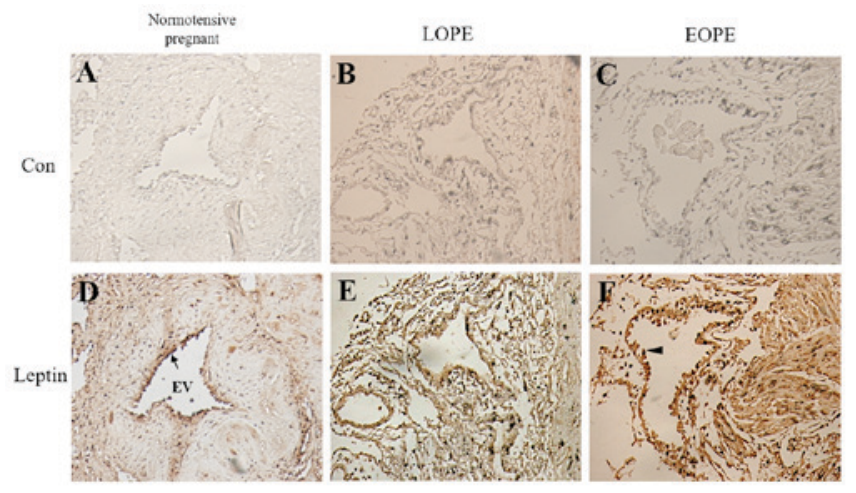

Figure 4. Immunostaining for leptin in the placental bed. Control staining without a primary antibody was performed for (A) normotensive control (38 weeks gestational age), (B) LOPE (37 weeks +1 day gestational age) and (C) EOPE (33 weeks +4 days gestational age) groups. Placental bed tissues from the (D) normotensive control, (E) LOPE and (F) EOPE were analyzed by immunohistochemistry with a primary antibody against leptin. Flattened endothelial cells are indicated by the arrow in the normotensive group, while the arrow head indicates cuboidal endothelial cells in the EOPE group. (magnification, x400). LOPE, late-onset preeclampsia; EOPE, early-onset preeclampsia; EV, endovascular trophoblast; Con, negative control staining without a primary antibody.

in the third trimester placental bed from patients with PE and normotensive controls, and indicated an association between the expression of these factors in the placental bed and the pathogenesis of PE. 
Dysregulation of leptin during pregnancy has been associated with the pathogenesis of various maternal complications, including PE, fetal growth restriction and gestational diabetes (9). However, mechanisms underlying pathogenesis of PE, as well as the effects of leptin on pregnancy, are diverse (11). Therefore, the association between the elevated expression of leptin and HIF-1 $\alpha$ in the placental bed and PE remains to be elucidated, but several mechanisms have been postulated.

One potential mechanism involves the angiogenic property of leptin. Placental hypoperfusion-ischemia has been hypothesized to be the major pathogenic mechanism underlying PE, resulting in hypoxia (11). Hypoxia was reported to increase VEGF production and the expression of placental leptin $(11,41)$. The association between leptin and angiogenesis is complex. According to in vitro studies on cytotrophoblasts and human vascular endothelial cells, leptin inhibited angiogenesis $(14,15)$. In one study, the level of leptin mRNA expression was associated with the expression levels of placental HIF-1 $\alpha$ mRNA (10). The present study demonstrated that placental bed leptin and HIF-1 $\alpha$ expression was markedly increased in patients with PE compared with normotensive controls. Therefore, it may be hypothesized that reduced placental perfusion and hypoxia caused by PE results in an increased production of leptin, which may further inhibit angiogenesis in endothelial cells.

Another plausible mechanism to be considered is the association of leptin with inflammation $(16,17)$. The expression and release of leptin is affected by inflammatory cytokines, including tumor necrosis factor (TNF)- $\alpha$, interleukin (IL)- $1 \alpha$ and IL-6 (42). Previous studies have hypothesized that increased production of systemic inflammatory cytokines may result in PE due to impaired trophoblast invasion with vascular damage during spiral artery remodeling (43-45). The endothelial cells observed by immunostaining in the present study exhibited hypertrophic cuboidal morphology with ovoid nuclei which indicated possible cell damage (46). The present study demonstrated that PE groups manifested damaged endothelial cells of the intima, while the normotensive group exhibited normal endothelial cells with a flattened morphology. Therefore, it may be hypothesized that elevated leptin expression in the placental bed may be a consequence of endothelial cell damage induced by increased inflammation. However, further studies investigating the expression of inflammatory cytokines and leptin in the placental bed are required to verify this hypothesis.

Previous studies have investigated the expression of the leptin receptor in PE. Klaffenbach et al (23) demonstrated increased expression of leptin receptor in placental cells under hypoxic conditions, while other studies revealed no difference in leptin receptor expression between normotensive controls, and mild and severe PE groups $(10,12)$. The present study determined the expression of leptin receptor isoforms in the placental bed and revealed no differences between the normotensive control and PE groups. Therefore, the results of the present study indicate that the degree of leptin expression may have been below the effective level to trigger upregulation of the leptin receptor, or that the development of PE may be influenced by leptin rather than the amount of leptin receptor under hypoxic conditions.
In conclusion, the expression of leptin, its receptor and HIF- $1 \alpha$ in the third trimester placental bed of pregnancies with PE was investigated in the present study and significant alterations of leptin expression associated with onset period were detected. The results indicated that leptin and HIF-1 $\alpha$ expression level in the placental bed may be associated with the development and onset period of PE. Although the results of the present study demonstrate differential expression of leptin and HIF-1 $\alpha$ between the normotensive control and the PE groups, certain limitations are present. Experimental samples were obtained from third trimester placental beds and it cannot be established whether the alterations are a cause or a consequence of established PE. Although the pathological alterations of PE were examined after the gestation period was complete, samples (blood or placenta) in early or mid-trimesters were not examined in the current study. Further studies based on a larger number of diverse samples may further confirm the association between leptin and the pathogenesis of PE, and elucidate the precise molecular mechanisms underlying this association.

\section{Acknowledgements}

Not applicable.

\section{Funding}

The present study was supported by a grant from the Korea Healthcare Technology Research and Development Project, Ministry of Health and Welfare, Korea (grant no. A100060) and assisted by the Department of Biostatistics, Clinical Trial Center, Biomedical Research Institute, Pusan National University Hospital (Busan, Korea).

\section{Availability of data and materials}

The analyzed data sets generated during the study are available from the corresponding author on reasonable request.

\section{Authors' contributions}

MJP and SCK conceived the idea and designed the experiments. MJP, BSJ and YJL did experiments and analysis of results. DHL contributed to the idea generation. JKJ, SCK and KSL provided resources. MJP, BSA and SCK wrote the manuscript.

\section{Ethics approval and consent to participate}

The Institutional Review Board of Pusan National University Hospital approved the research protocol of the present study (approval no. 1302-005-015) and all participants signed written informed consent forms prior to recruitment.

\section{Consent for publication}

Written informed consent was obtained from all participants.

\section{Competing interests}

The authors declare that they have no competing interests. 


\section{References}

1. American College of Obstetricians and Gynecologists; Task Force on Hypertension in Pregnancy: Hypertension in pregnancy. Report of American college of obstetricians and Gynecologists Task Force on hypertension in pregnancy. Obstet Gynecol 122 1122-1131, 2013

2. Meekins JW, Pijnenborg R, Hanssens M, McFadyen IR and van Asshe A: A study of placental bed spiral arteries and trophoblast invasion in normal and severe pre-eclamptic pregnancies Br J Obstet Gynaecol 101: 669-674, 1994.

3. Burton GJ and Jauniaux E: Placental oxidative stress: From miscarriage to preeclampsia. J Soc Gynecol Investig 11: 342-352, 2004.

4. Steegers EA, von Dadelszen P, Duvekot JJ and Pijnenborg R: Pre-eclampsia. Lancet 376: 631-644, 2010.

5. Lash GE, Cartwright JE, Whitley GS, Trew AJ and Baker PN: The effects of angiogenic growth factors on extravillous trophoblast invasion and motility. Placenta 20: 661-667, 1999.

6. Distler JH, Hirth A, Kurowska-Stolarska M, Gay RE, Gay S and Distler O: Angiogenic and angiostatic factors in the molecular control of angiogenesis. Q J Nucl Med 47: 149-161, 2003.

7. Schiessl B, Innes BA, Bulmer JN, Otun HA, Chadwick TJ, Robson SC and Lash GE: Localization of angiogenic growth factors and their receptors in the human placental bed throughout normal human pregnancy. Placenta 30: 79-87, 2009.

8. Sugathadasa BH, Tennekoon KH, Karunanayake EH, Kumarasiri JM and Wijesundere AP: Association of -2548 G/A polymorphism in the leptin gene with preeclampsia/pregnancy-induced hypertension. Hypertens Pregnancy 29: 366-374, 2010.

9. Sagawa N, Yura S, Itoh H, Kakui K, Takemura M, Nuamah MA, Ogawa Y, Masuzaki H, Nakao K and Fujii S: Possible role of placental leptin in pregnancy: A review. Endocrine 19: 65-71, 2002.

10. Iwagaki S, Yokoyama Y, Tang L, Takahashi Y, Nakagawa Y and Tamaya T: Augmentation of leptin and hypoxia-inducible factor 1alpha mRNAs in the pre-eclamptic placenta. Gynecol Endocrinol 18: 263-268, 2004.

11. Mise H, Sagawa N, Matsumoto T, Yura S, Nanno H, Itoh H, Mori T, Masuzaki H, Hosoda K, Ogawa Y and Nakao K: Augmented placental production of leptin in preeclampsia: Possible involvement of placental hypoxia. J Clin Endocrinol Metab 83: 3225-3229, 1998

12. Sierra-Honigmann MR, Nath AK, Murakami C, García-Cardeña G, Papapetropoulos A, Sessa WC, Madge LA, Schechner JS, Schwabb MB, Polverini PJ and Flores-Riveros JR Biological action of leptin as an angiogenic factor. Science 281: 1683-1686, 1998

13. Garonna E, Botham KM, Birdsey GM, Randi AM, GonzalezPerez RR and Wheeler-Jones CP: Vascular endothelial growth factor receptor- 2 couples cyclo-oxygenase- 2 with pro-angiogenic actions of leptin on human endothelial cells. PLoS One 6: e18823, 2011.

14. Islami D, Bischof P and Chardonnens D: Modulation of placental vascular endothelial growth factor by leptin and hCG. Mol Hum Rep 9: 395-398, 2003

15. Bohlen F, Kratzsch J, Mueller M, Seidel B, Friedman-Einat M, Witzigmann H, Teupser D, Koerner A, Storck M and Thiery J: Leptin inhibits cell growth of human vascular smooth muscle cells. Vascul Pharmacol 46: 67-71, 2007.

16. Meller M, Qiu C, Kuske BT, Abetew DF, Muy-Rivera M and Williams MA: Adipocytokine expression in placentas from pre-eclamptic and chronic hypertensive patients. Gynecol Endocrinol 22: 267-273, 2006

17. Linnemann K, Malek A, Schneider H and Fusch C: Physiological and pathological regulation of feto/placento/maternal leptin expression. Biochem Soc Trans 29: 86-90, 2001.

18. Sacks GP, Studena K, Sargent K and Redman CW: Normal pregnancy and preeclampsia both produce inflammatory changes in peripheral blood leukocytes akin to those of sepsis. Am J Obstet Gynecol 179: 80-86, 1998 .

19. Han L, Liu X, Li H, Zou J, Yang Z, Han J, Huang W, Yu L, Zheng Y and Li L: Blood coagulation parameters and platelet indices: Changes in normal and preeclamptic pregnancies and predictive values for preeclampsia. PLoS One 9: e114488, 2014.

20. Lu Z, Wang F and Liang M: SerpinC1/antithrombin III in kidney-related diseases. Clin Sci 131: 823-831, 2017.
21. Li RH, Poon SC, Yu MY and Wong YF: Expression of placental leptin and leptin receptors in preeclampsia. Int $\mathrm{J}$ Gynecol Pathol 23: 378-385, 2004

22. Challier J, Galtier M, Bintein T, Cortez A, Lepercq J and Hauguel-de Mouzon S: Placental leptin receptor isoforms in normal and pathological pregnancies. Placenta 24: 92-99, 2003.

23. Klaffenbach D, Meissner U, Raake M, Fahlbusch F, Alejandre Alcazar MA, Allabauer I, Kratzsch J, Rascher W and Dötsch J: Upregulation of leptin-receptor in placental cells by hypoxia. Regul Pept 167: 156-162, 2011.

24. Grosfeld A, Andre J, Hauguel-De Mouzon S, Berra E, Pouyssegur J and Guerre-Millo M: Hypoxia-inducible factor 1 transactivates the human leptin gene promoter. J Biol Chem 277: 42953-42957, 2002.

25. Wang F, Zhang G, Xing T, Lu Z, Li J, Peng C, Liu G and Wang N: Renalase contributes to the renal protection of delayed ischaemic preconditioning via the regulation of hypoxia-inducible factor- $1 \alpha$. J Cell Mol Med 19: 1400-1409, 2015

26. Lu D, Yang X, Wu Y, Wang H, Huang H and Dong M: Serum adiponectin, leptin and soluble leptin receptor in pre-eclampsia. Int J Gynaecol Obstet 95: 121-126, 2006.

27. Genbacev O, Joslin R, Damsky CH, Polliotti BM and Fisher SJ: Hypoxia alters early gestation human cytotrophoblast differentiation/invasion in vitro and models the placental defects that occur in preeclampsia. J Clin Invest 97: 540-550, 1996.

28. Dixon HG and Robertson WB: A study of the vessels of the placental bed in normotensive and hypertensive women. J Obstet Gynaecol Br Emp 65: 803-809, 1958.

29. Robson SC, Simpson H, Ball E, Lyall F and Bulmer JN: Punch biopsy of the human placental bed. AM J Obstet Gynecol 187: $1349-1355,2002$

30. Kaufmann P, Black S and Huppertz B: Endovascular trophoblast invasion: Implications for the pathogenesis of intrauterine growth retardation and preeclampsia. Biol Reprod 69: 1-7, 2003.

31. Laml T, Preyer O, Hartmann BW, Ruecklinger E, Soeregi G and Wagenbichler P: Decreased maternal serum leptin in pregnancies complicated by preeclampsia. J Soc Gynecol Investig 8: 89-93, 2001.

32. Martinez-Abundis E, Gonzalez-Ortiz M and Pascoe-Gonzalez S: Serum leptin levels and the severity of preeclampsia. Arch Gynecol Obstet 264: 71-73, 2000.

33. Laml T, Hartmann BW, Preyer O, Ruecklinger E, Soeregi G and Wagenbichler P: Serum leptin concentration in cord blood: Relationship to birth weight and gender in pregnancies complicated by pre-eclampsia. Gynecol Endocrinol 14: 442-447, 2000.

34. Lappas M, Yee K, Permezel M and Rice GE: Release and regulation of leptin, resistin and adiponectin from human placenta, fetal membranes and maternal adipose tissue and skeletal muscle from normal and gestational diabetes mellitus-complicated pregnancies. J Endocrinol 186: 457-465, 2005.

35. Laivuori H, Gallaher MJ, Collura L, Crombleholme WR, Markovic N, Rajakumar A, Hubel CA, Roberts JM and Powers RW: Relationships between maternal plasma leptin, placental leptin mRNA and protein in normal pregnancy, pre-eclampsia and intrauterine growth restriction without pre-eclampsia. Mol Hum Reprod 12: 551-556, 2006.

36. Tranquilli AL, Brown MA, Zeeman GG, Dekker G and Sibai BM: The definition of severe and early-onset preeclampsia. Statements from the International Society for the Study of Hypertension in Pregnancy (ISSHP). Pregnancy Hypertens 3: 44-47, 2013.

37. Lyall F: The human placental bed revisited. Placenta 23: 555-562, 2002.

38. Kim SC,Park MJ, Joo BS, Joo JK, Suh DS and Lee KS: Decreased expressions of vascular endothelial growth factor and visfatin in the placental bed of pregnancies complicated by preeclampsia. J Obstet Gynaecol Res 38: 665-673, 2012

39. Livak KJ and Schmittgen TD: Analysis of relative gene expression data using real-time quantitative PCR and the 2(-Delta Delta C(T)) method. Methods 25: 402-408, 2001.

40. Sattar N, Greer IA, Pirwani I, Gibson J and Wallace AM: Leptin levels in pregnancy: Marker for fat accumulation and mobilization? Acta Obstet Gynecol Scand 77: 278-283, 1998.

41. Delforce SJ, Wang Y, Van-Aalst ME, Corbisier de Meaultsart C, Morris BJ, Broughton-Pipkin F, Roberts CT, Lumbers ER, Pringle KG, et al: Effect of oxygen on the expression of reninangiotensin system components in a human trophoblast cell line. Placenta 37: 1-6, 2016. 
42. Nuamah MA, Yura S, Sagawa N, Itoh H, Mise H, Korita D, Kakui K, Takemura M, Ogawa Y, Nakao K and Fujii S: Significant increase in maternal plasma leptin concentration in induced delivery: A possible contribution of pro-inflammatory cytokines to placental leptin secretion. Endocr J 51: 177-187, 2004.

43. Lockwood CJ, Yen CF, Basar M, Kayisli UA, Martel M, Buhimschi I, Buhimschi C, Huang SJ, Krikun G and Schatz F: Preeclampsia-related inflammatory cytokines regulate interleukin-6 expression in human decidual cells. AM J Pathol 172: $1571-1579,2008$
44. Matthiesen L, Berg G, Ernerudh J, Ekerfelt C, Jonsson Y and Sharma S: Immunology of preeclampsia. Chem Immunol Allergy 89: 49-61, 2005.

45. Poston L: Endothelial dysfunction in pre-eclampsia. Pharmacol Rep 58 (Suppl): S69-S74, 2006.

46. Cotran RS, Kumar V and Robbins SL: Robbins Pathologic Basis of Disease. 4th edition. Saunders, Philadelphia, 1989. 